\title{
Pengaruh Ukuran Perusahaan, Political Cost Dan Kinerja Lingkungan Terhadap Environmental Disclosure Dalam Laporan Tahunan
}

\author{
Ni Kadek Dwi Nana Ulan Noviani ${ }^{1}$ \\ Fakultas Ekonomi dan Bisnis \\ Universitas Udayana, Indonesia. \\ Email: ulannov7@gmail.com
}

\author{
Ketut Alit Suardana ${ }^{2}$ \\ Fakultas Ekonomi dan Bisnis \\ Universitas Udayana, Indonesia.
}

\begin{abstract}
ABSTRAK
Environmental Disclosure merupakan pengungkapan yang dilakukan oleh perusahaan publik terkait dengan kewajibannya terhadap lingkungan dan masyarakat. Penelitian ini memiliki tujuan untuk mengetahui faktorfaktor yang mempengaruhi Environmental Disclosure, yakni ukuran perusahaan, political cots, dan kinerja lingkungan. Penelitian dilakukan pada perusahaan yang terdaftar di BEI periode 2014-2017 yang tergabung dalam sub sektor makanan dan minuman. Jumlah sampel yang diambil sebanyak 56 perusahaan, dengan metode probability sampling. Pengumpulan data dilakukan melalui analisis laporan keuangan perusahaan, yang dianalisis dengan regresi linear berganda. Berdasarkan hasil analisis ditemukan bahwa ukuran perusahaan secara parsial berpengaruh positif terhadap Environmental Disclosure. Political Cost berpengaruh positif terhadap Environmental Disclosure. Kinerja lingkungan berpengaruh positif terhadap Environmental Disclosure.
\end{abstract}

Kata Kunci: Environmental Disclosure, Ukuran, Political Cost, Kinerja.

\section{Effect of Company Size, Political Cost and Environmental Performance on Environmental Disclosure in the Annual Report}

\section{ABSTRACT}

Environmental Disclosure is disclosure made by public companies related to their obligations to the environment and society. This study aims to determine the factors that influence Environmental Disclosure, namely the size of the company, political cots, and environmental performance. The study was conducted at companies listed on the Stock Exchange for the period 2014-2017 which are incorporated in the food and beverage sub-sector. The number of samples taken were 56 companies, with probability sampling methods. Data collection is done through analysis of company financial statements, which are analyzed by multiple linear regression. Based on the results of the analysis it was found that the size of the company partially had a positive effect on Environmental Disclosure. Political Cost has a positive effect on Environmental Disclosure. Environmental performance has a positive effect on Environmental Disclosure

Keywords: Enviromental disclosure, Size, Political Cost, Performance.

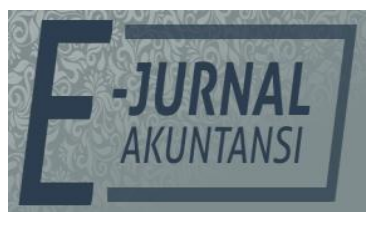

E-JA

e-Jurnal Akuntansi e-ISSN 2302-8556

Denpasar, Vol. 28 No. 3

September 2019 Hal. 1904-1919

Artikel masuk: 18 Juni 2019

Tanggal diterima: 21 Agustus 2019 


\section{PENDAHULUAN}

Perusahaan dalam menjalankan operasionalnya, memiliki tanggung jawab untuk meningkatkan laba demi kepentingan pemegang saham (stakeholders), tetapi juga harus memperhatikan lingkungan (environment) dan masyarakat (people) tempatnya melakukan kegiatan usaha. Maraknya isu kerusakan lingkungan oleh perusahaan yang tidak bertanggung jawab menuntut pemerintah untuk semakin memperketat aturan terkait pemeliharaan lingkungan dan tanggungjawab sosial bagi perusahaan. Undang-Undang No. 74 tahun 2007 merupakan wujud nyata kepedulian pemerintah dalam menanggapi isu semacam ini. Peraturan tersebut membuat semakin konkritnya tugas perusahaan terutama yang bergerak tidak jauh dari pemanfaatan lingkungan dalam memenuhi tanggungjawab sosial perusahaan. Perusahaan yang operasionalnya berhubungan langsung dengan sumber daya alam salah satunya adalah perusahaan yang bergerak di sektor makanan dan minuman.

Kementrian Lingkungan Hidup dan Kehutanan melalui Direktorat Jenderal Penegakan Hukum (Gakkum) LHK telah melakukan penanganan terhitung sejak tahun 2015 hingga bulan April 2018 telah menerima lebih dari 2.000 pengaduan terkait kurangnya kepekaan perusahaan pada lingkungan, mengawasi sebanyak 462 perusahaan terkait perijinan. Kementrian Lingkungan Hidup juga telah memberikan sanksi kepada 50 lebih perusahaan sebagai dampak pelanggaran limbah bahan beracun, dan kasus lain yang telah berada pada tahap persidangan (Rasio, 2018). Pengungkapan informasi yang transparan terkait tanggungjawab sosial dan lingkungan dapat memberikan dampak positif bagi perusahaan, tidak hanya sebagai bentuk ketaatan terhadap aturan pemerintah, tetapi juga menarik minat investor untuk menanamkan modalnya pada perusahaan tersebut. Perusahaan yang menjalankan kewajiban lingkungannya akan mendapatkan citra positif dari masyarakat (Winarsih, 2015). Program Penilaian Peringkat Kinerja Perusahaan dalam Pengelolaan Lingkungan Hidup (PROPER) merupakan produk Kementerian Lingkungan Hidup untuk memberikan penilaian pada perusahaan yang telah melakukan pelestarian lingkungan, dan menjaga lingkungannya. Perusahaan makanan dan minuman yang menjadi peserta PROPER dan terdaftar di BEI sebanyak 14 perusahaan dalam periode 4 terakhir 2014-2017 ditunjukkan dalam tabel 1.

Tabel 1. Daftar perusahaan makanan dan minuman di Bursa Efek Indonesia dan menjadi peserta PROPER

\begin{tabular}{cll}
\hline No & Kode Saham & \multicolumn{1}{c}{ Nama Emiten } \\
\hline 1 & CAMP & Campina Ice Cream Industry Tbk \\
2 & CEKA & Wilmar Cahaya Indonesia Tbk, PT \\
3 & DLTI & Delta Djakarta Tbk, PT \\
4 & ICBP & Indofood CBP Sukses Makmur Tbk. PT \\
5 & INDF & Indofood Sukses Makmur Tbk, PT \\
6 & MLBI & Multi Bintang Indonesia, Tbk \\
7 & MYOR & Mayora Indah Tbk., PT \\
\hline
\end{tabular}

Bersambung ... 
Lanjutan Tabel 1.

\begin{tabular}{cll}
\hline 8 & ULTJ & Ultrajaya Milk Industry and Trading Company Tbk \\
9 & AISA & PT Tiga Pilar Seahtera Tbk \\
10 & ALTO & PT Tri Bayan Tirta Tbk \\
11 & PSDN & PT Prashida Aneka Niaga \\
12 & ROTI & Nippon Indosari Corporation \\
13 & STTP & PT Siantar Top Tbk \\
14 & ADES & Ades Waters Indonesia Tbk \\
\hline
\end{tabular}

Sumber: Data Penelitian, 2018

Pengungkapan lingkungan sebagai upaya perusahaan untuk menjaga lingkungan sekitar sehingga menciptakan hubungan harmonis dengan alam dan manusia. Pengungkapan lingkungan ini dapat dilaporkan setiap tahun yang dituangkan dalam pelaporan tanggungjawab sosial perusaaan yang terdapat dalam laporan tahunan (annual report). Pelaporan lingkungan sebenarnya merupakan bagian dari laporna keuangan yang dapat menjadi pertimbangan bagi investor untuk berinvestasi (Burgwal \& Vieira, 2014). Penelitian terkait pengungkapan lingkungan telah banyak dilakukan. Burgwal \& Vieira, (2014) meneliti hubungan enviromental disclosure dengan ukuran perusahaan, tipe industri, dan profitabilitas. Hasil yang diperoleh bahwa enviromental disclosure dipengaruhi oleh ukuran perusahaan dan tipe industri. Lebih lanjut penelitian Environmental Disclosure dilakukan oleh Akrout \& Othman, (2014) dengan hasil Environmental Disclosure dipengaruhi secara positif oleh budaya bisnis dan penetrasi internet. Penelitian Suhardjanto, et al., (2008) menghasilkan ukuran perusahaan berpengaruh positif signifikan terhadap Environmental Disclosure.

Ukuran perusahaan menunjukkan tingkat kepemilikan aset perusahaan, yang berpengaruh pada pandangan pemerintah, stakeholders, dan masyarakat terhadapnya. Perusahaan dengan aset yang besar tentu akan semakin dikenal masyarakat dan dituntut untuk melaporkan tanggungjawab sosial dna lingkungannya. Penelitian terdahulu terkait hubungan ukuran perusahaan dengan pengungkapan lingkungan menmperoleh hasil beragam. Tidak seperti penelitian Burgwal \& Vieira, (2014) yang memperoleh hasil bahwa kedua variabel tersebut berhubungan, penelitian Miranti, (2009) justru mendapatkan hasil yang berlawanan, bahwa ukuran perusahaan tidak berpengaruh pada Environmental Disclosure.

Biaya politis (political cost) merupakan hal utama adalam hubungan antara praktek manajemen laba dengan pengungkapan lingkungan perusahaan. Biaya politis diproksikan dengan market share. Perusahaan dengan market share yang tinggi memiliki jaringan usaha yang lebih luas dan lebih dikenal, sehingga mendapat tekanan yang lebih besar oleh masyarakat dalam pengungkapan tanggungjawab lingkungannya. Penelitian Fajrini (2012) memperoleh hasil bahwa biaya politis berpengaruh positif terhadap pengungkapan pertanggungjawaban sosial. Kinerja lingkungan merupakan salah satu hal yang dapat dilihat untuk mengukur tanggung jawab lingkungan suatu perusahaan. Penelitian ini menggunakan PROPER sebagai proksi kinerja lingkungan. 
Pengungkapan lingkungan dinilai dengan menggunakan kriteria Global Reporting Initiative. Perusahaan yang memperoleh peringkat tinggi dalam PROPER maka memiliki nilai pengungkapan lingkungan yang tinggi pula. Dewasa ini mengungkapkan informasi lingkungan menjadi fokus penting untuk setiap perusahaan untuk menarik simpati masyarakat dan memperoleh dukungan oleh masyarakat sekitar, serta bentuk kepatuhan pada aturan pemerintah.

Teori Legitimasi didefinisikan oleh Dowling \& Pfeffer (1975: 122) memiliki fokus utama yaitu hubungan antara perusahaan dan masyarakat. Gray, et al., (1995) menjelaskan teori legitimasi memiliki keunggulan dibandingkan teoriteori lain karena teori ini memberikan strategi pengungkapan yang dapat diadopsi organisasi untuk melegitimasi keberadaan mereka yang dapat diuji secara empiris. Teori legitimasi berpendapat bahwa organisasi melakukan identifikasi dan menentukan upaya yang tepat untuk menjamin operasi mereka tidak menyalahi aturan masyarakat. Dalam mengadopsi perspektif teori legitimasi, perusahaan akan secara sukarela melaporkan kegiatan jika manajemen merasa bahwa kegiatan tersebut diharapkan oleh masyarakat di mana ia beroperasi (Deegan, 2002). Perusahaan akan mengungkapkan lebih banyak tentang lingkungan di mana ancaman terhadap legitimasi mereka tinggi dan kurang mengungkapkan ketika legitimasi mereka tidak diancam dengan cara apa pun oleh masyarakat (Welbeck, et al., 2018).

Pengungkapan lingkungan menjadi isu penting dalam keberlangsungan suatu perusahaan. Pengungkapan tanggung jawab lingkungan menjadi faktor yang tak kalah penting sebagai bahan pertimbangan investor. Suratno, et al., (2007) menyatakan Environmental Disclosure sebagai suatu informasi dalam laporan tahunan yang berhubungan dengan sumber daya alam dan lingkungan. Pengungkapan lingkungan sangat penting sebagai bahan pertimbangan dalam mengambil keputusan ekonomi, sosial, maupun politik antara pemerintah, masyarakat, dan investor (Nugraha, 2015). Pengungkapan lingkungan perusahaan juga berisi informasi tentang implikasi keuangan masa lalu, saat ini, dan masa depan yang dihasilkan dari keputusan atau tindakan manajemen lingkungan perusahaan (Berthelot \& Magnan, 2017). Ukuran perusahaan merupakan indikator untuk menentukan besar kecilnya suatu perusahaan yang dapat dilihat dari total aset, maupun total penjualan. Ditemukan bahwa perusahaan besar di sektor yang berkaitan dengan masalah lingkungan memiliki kualitas pengungkapan yang tinggi (Sahore, 2017).

Biaya politis menunjukkan perkembangan usaha sebuah perusahaan. Market share yang luas membuat mereka lebih ditekan untuk bertanggungjawab kepada lingkungannya. Sejak tingkat biaya politik dikaitkan dengan ukuran perusahaan, oleh karena itu ukuran perusahaan akan mempengaruhi keputusan manajemen untuk secara sukarela mengungkapkan informasi untuk menghindari biaya politis. Perusahaan yang lebih besar akan memiliki kebutuhan yang lebih besar untuk mengurangi biaya politik daripada perusahaan yang lebih kecil (Darus \& Taylor, 2009). Manajer akan berusaha untuk membuat laba seolah-olah kecil dengan metode akuntansi tertentu demi untuk menutupi political cost yang tinggi (Milne, 2017). Market share sebagai proksi political cost menunjukkan persebaran pangsa pasar perusahaan. Perusahaan dengan market share tinggi menunjukkan bahwa mereka memperoleh 
laba yang tinggi pula. Hal tersebut haruslah sebanding dengan pemenuhan kewajiban perusahaan terhadap lingkungan, untuk menghindari protes sosial yang kemungkinan dilakukan oleh masyarakat. Tanggung jawab lingkungan ini menjadi wujud usaha perusahaan dalam mempertanggungjawabkan efek yang ditimbulkan dari kegiatan usahanya terhadap lingkungan dan masyarakat sekitarnya.

Kinerja lingkungan merupakan usaha perusahaan untuk menjaga dan meminimalisir dampak dari kegiatan operasionalnya terhadap lingkungan. Ukuran untuk menilai kinerja lingkungan di Indonesia ada berbagai macam, namun dalam penelitian ini penulis menggunakan PROPER. Dalam PROPER peserta bersifat selektif, yang ditujukan kepada perusahaan yang memiliki dampak yang besar pada lingkungan. Kinerja penataan yang dinilai dalam PROPER mencakup: penataan terhadap pengendalian pencemaran air, udara, pengeloalaan limbah B3, dan penerapan AMDAL. PROPER memberikan peringkat pada perusahaan sesuai dengan tingkat kepeduliannya terhadap lingkungan yang ditandai dengan beberapa warna, yaitu Emas, Hijau, Biru, Merah dan Hitam.

Teori stakeholder menjelaskan bahwa para pemangku kepentingan memiliki hak dan kewajiban yang besar dalam mengontrol dan mengawasi sumber daya perusahaan. Perusahaan dengan ukuran yang besar (dilihat dari total asetnya) tentu memiliki pemangku kepentingan yang lebih banyak dibandingan dengan perusahaan yang berukuran kecil. Hal ini menyebabkan perusahaan besar akan melakukan dengen sebaiknya dalam hal pengungkapan lingkungan demi memuaskan para penanam modal. Sejalan dengan teori legitimiasi yang menyatakan bahwa perusahaan besar cenderung lebih dikenal masyarakat, sehingga mereka akan dituntut untuk memenuhi kewajiban lingkungannya. Oleh karena itu perusahaan akan membuat Environmental Disclosure untuk mempertahankan legitimasinya di lingkungan operasional. Penelitian oleh Suttipun \& Stanton, (2012) memperoleh hasil bahwa ukuran perusahaan berpengaruh positif pada Environmental Disclosure. Hasil tersebut sejalan dengan penelitian Hadjoh \& Sukartha, (2013) yaitu ukuran perusahaan berpengaruh positif pada besarnya pengungkapan lingkungan yang dicantumkan dalam laporan keuangan. Sesuai uraian di atas, maka dapat dirumuskan hipotesis pertama sebagai berikut.

$\mathrm{H}_{1}$ : Ukuran perusahaan berpengaruh positif terhadap Environmental Disclosure.

Teori Political Cost menjelaskan bahwa perusahaan besar cenderung akan menggunakan metode akuntansi yang dapat mengurangi laba untuk meningkatkan biaya politis (Setyorini \& Soedirman, 2012). Market share yang tinggi menunjukkan pula cakupan pasar perusahaan yang luas, dan keuntungan yang tinggi, dimana hal ini menyebabkan tekanan yang lebih besar dari masyarakat agar perusahaan lebih memperhatikan lingkungannya. Tingginya market share dan keuntungan perusahaan seharusnya dapat sesuai dengan timbal balik yang diberikan kepada lingkungan sekitar. Hal inilah yang menyebabkan tekanan untuk perhatian terhadap lingkungan menjadi lebih besar.

Teori legitimasi sendiri telah memberikan penjelasan mengenai perusahaan akan memberikan laporan pengungkapan lingkungan sebagai wujud kepeduliannya terhadap lingkungan sekitar, mengatasi tekanan yang diberikan, 
serta mencegah legitimacy gap yang dapat terjadi sebagai akibat dari kegiatan usaha yang dilakukan. Uraian tersebut membawa kita pada rumusan hipotesis kedua, yakni.

$\mathrm{H}_{2}$ : Political Cost berpengaruh positif terhadap Environmental Disclosure.

Teori legitimasi menyatakan bahwa perusahaan yang memiliki kinerja lingkungan yang baik cenderung akan melakukan Environmental Disclosure sebagai wujud ketaatan terhadap undang-undang, serta menarik minat investor untuk menanamkan modalnya. Environmental Disclosure juga nyatanya dapat menjadi alat untuk menarik simpati dan meningkatkan citra perusahaan di mata masyarakat. Perusahaan yang mampu menunjukkan kinerja lingkungannya akan memperoleh sinyal yang baik dari lingkungan sekitarnya (Cong \& Freedman, 2011). Sejalan dengan teori stakeholders, perusahaan akan bertindak sesuai dengan keinginan pemegang saham, maka dari itu perusahaan mengungkapkan lingkungan guna menarik minat para penanam modal.

Pengungkapan lingkungan dan kinerja lingkungan memiliki hubungan positif (Cedric \& Fraas, 2011). Sejalan dengan penelitian oleh Clarkson, et al., (2007) dan Tuwaijri, et al., (2004), dimana keduanya menunjukkan hasil yang sama terkait adanya pengaruh positif antara kinerja lingkungan dengan pengungkapan lingkungan. Uraian tersebut merumuskan hipotesis ketiga sebagai berikut.

$\mathrm{H}_{3}$ : Kinerja lingkungan berpengaruh positif terhadap Environmental Disclosure.

\section{METODE PENELITIAN}

Pengungkapan lingkungan merupakan pengungkapan tanggungjawab lingkungan yang biasanya dilakukan oleh perusahaan yang berhubungan dengan sumber daya alam. Perusahaan sub sektor makanan dan minuman merupakan perusahaan yang bergerak langsung dalam hubungannya dengan sumber daya alam. Penelitian ini dilakukan pada perusahaan sub sektor makanan dan minuman yang terdaftar di BEI dan merupakan peserta PROPER. Populasi yang digunakan dalam penelitian ini adalah perusahaan sub sektor makanan dan minuman yang terdaftar pada BEI, dan sebagai anggota PROPER sesuai yang disebutkan dalam Kementrian Lingkungan Hidup. Sampel dalam penelitian ini mengambil perusahaan dalam periode empat tahun terakhir dimulai dari tahun 2014 sampai dengan tahun 2017 yang berjumlah 56 perusahaan. Sampel ditentukan dengan metode nonprobability sampling yaitu purposive sampling dengan menggunakan kriteria seperti yang telah dijelaskan sebelumnya.

Penelitian ini mengkaji bagaimana pengaruh ukuran perusahaan, political cost diproksikan melalui market share, dan kinerja lingkungan terhadap environmental disclosure pada perusahaan Sub Sektor Makanan dan Minuman yang terdaftar di BEI dan menjadi peserta PROPER. Gambar berikut memperlihatkan desain dalam penelitian ini. 


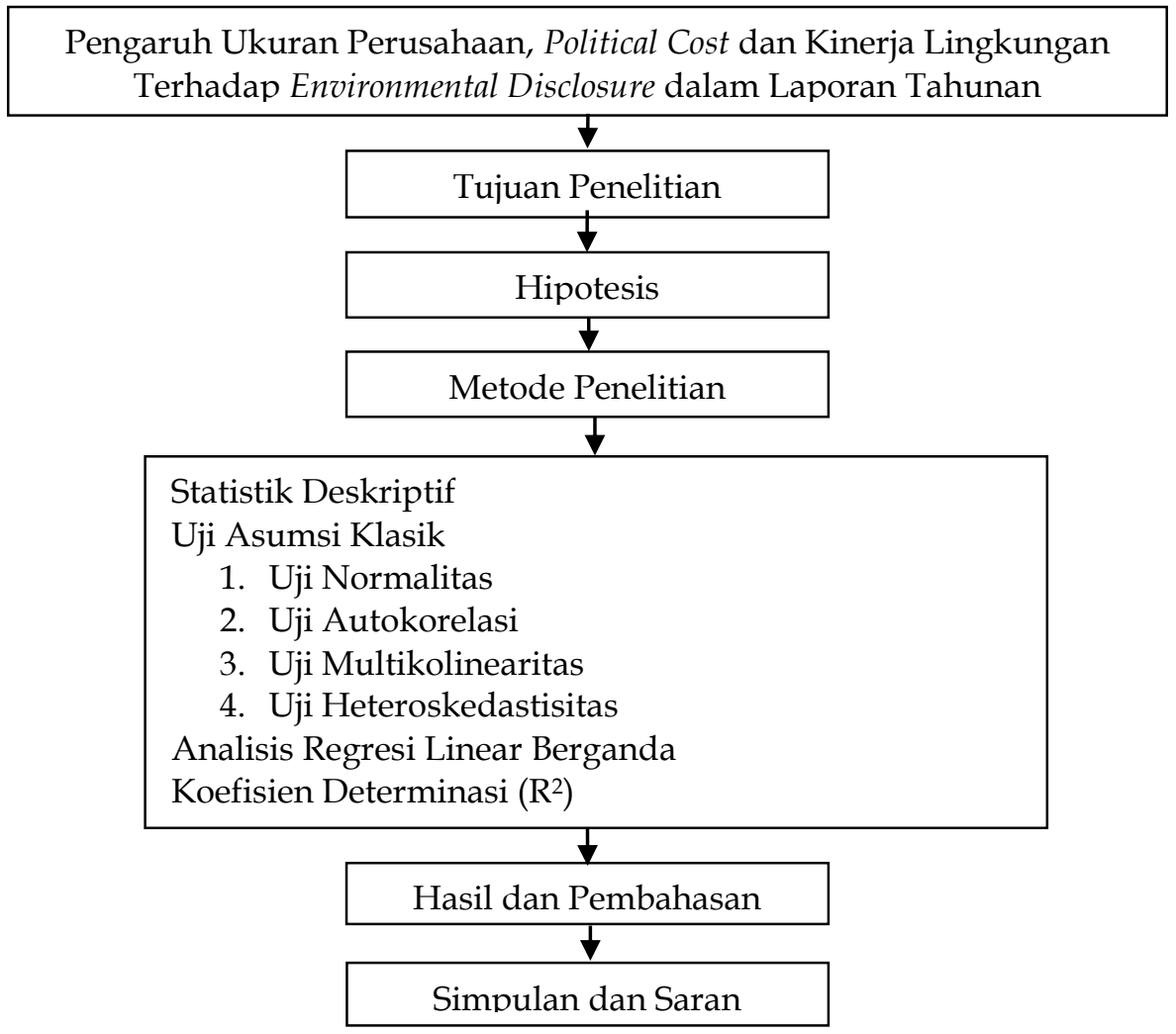

Sumber: Data Penelitian, 2018

\section{Gambar 1. Desain Penelitian}

Pengumpulan data dilakukan dengan metode dekomentasi yaitu dengan melihat, mencatat, dan mengumpulkan data dari BEI di laman www.idx.co.id, dan peserta PROPER yang diperoleh dari laman Kementrian Lingkungan Hidup www.menlh.go.id. Teknik analisis data menggunakan regresi linear berganda, dengan rumus berikut.

$Y=\alpha+\beta_{1} X_{1}+\beta_{2} X_{2}+\beta_{3} X_{3}+e$

Keterangan:

$\begin{array}{ll}\mathrm{Y} & \text { : Environmental Disclosure (ED) (skor GRI) } \\ \mathrm{a} & : \text { Nilai Konstanta } \\ \beta_{1}-\beta_{3} & : \text { Koefisien regresi } \\ \mathrm{X}_{1} & : \text { Ukuran perusahaan (Ln total aset) } \\ \mathrm{X}_{2} & : \text { Political Cost (Market Share) } \\ \mathrm{X}_{3} & \text { : Kinerja lingkungan (peringkat PROPER) } \\ \mathrm{E} & \text { : Standard error }\end{array}$

\section{HASIL DAN PEMBAHASAN}

Sektor makanan dan minuman merupakan sektor yang memberikan kontribusi besar dalam pertumbuhan ekonomi di Indonesia. Semakin berkembangnya kebutuhan pangan masyarakat menyebabkan perusahaan yang bergerak dalam bidang ini terus bertumbuh, dan memerlukan kepedulian yang lebih besar terhadap lingkungan sekitar tempatnya beroperasi. Sektor makanan dan minuman di BEI terdiri atas 21 perusahaan, namun hanya 14 yang masuk dalam kriteria sampel seperti yang terlihat pada tabel 2. 
Tabel 2. Seleksi Sampel Penelitian

\begin{tabular}{clc}
\hline No. & \multicolumn{1}{c}{ Kriteria } & Jumlah \\
\hline $1 \quad \begin{array}{l}\text { Perusahaan sektor makanan dan minuman yang terdaftar di } \\
\text { Bursa Efek Indonesia tahun 2014-2017 }\end{array}$ & 21 \\
$2 \quad \begin{array}{l}\text { Perusahaan-perusahaan sektor makanan dan minuman yang } \\
\text { tidak memuat data yang diperlukan dalam penelitian }\end{array}$ & 7 \\
$\begin{array}{l}\text { Jumlah sampel penelitian } \\
\begin{array}{l}\text { Tahun pengamatan } \\
\text { Total sampel sela } \\
\text { ma periode penelitian }\end{array}\end{array}$ & 14 \\
\hline
\end{tabular}

Sumber: Data Penelitian, 2018

Sesuai tabel 2, maka perusahaan sub sektor makanan dan minuman yang dijadikan sampel selama empat tahun terakhir berjumlah 56 perusahaan, sehingga peneliti akan melakukan penelitian di 56 perusahaan tersebut.

Statistik deskriptif digunakan untuk memperoleh gambaran suatu data yang dilihat dari nilai minimum, maksimum, rata-rata, dan simpangan baku, seperti yang bisa dilihat dalam tabel 3 .

Tabel 3. Hasil Uji Statistik Deskriptif

\begin{tabular}{llllll}
\hline & $\mathrm{N}$ & \multicolumn{1}{c}{ Minimum } & Maximum & Mean & Std. Deviation \\
\hline Ukuran Perusahaan & 56 & 20,72 & 32,60 & 28,9453 & 3,24076 \\
political cost & 56 & 0,0000012 & 0,44 & 0,0714 & 0,01035 \\
kinerja lingkungan & 56 & 1,00 & 2,84 & 1,2633 & 0,65075 \\
Environmental & 56 & 0,59 & 0,88 & 0,7568 & 0,07514 \\
Disclosure & & & & & \\
Valid N (listwise) & 56 & & & & \\
\hline
\end{tabular}

Sumber: Data Penelitian, 2018

Berdasarkan tabel 3 di atas menunjukkan bahwa jumlah data yang digunakan dalam penelitian ini adalah 56 sampel data yang diperoleh dari annual report dengan rentang waktu 4 tahun, yaitu dari tahun 2014 sampai dengan 2017.

Variabel Ukuran Perusahaan $\left(\mathrm{X}_{1}\right)$ memiliki nilai terendah (minimum) sebesar 20,72 dan nilai tertinggi (maximum) sebesar 32,60. Sementara standar deviasinya sebesar 3,24076 dan nilai rata-ratanya (mean) yaitu sebesar 28,9453. Standar devisasi lebih kecil dari skor rata-rata menunjukan bahwa Ukuran Perusahaan sebaran skornya semakin dekat dari skor rata-ratanya, yang mengindikasikan respon terhadap Ukuran Perusahaan tidak bervariasi.

Variabel political cost $\left(\mathrm{X}_{2}\right)$ mempunyai nilai terendah (minimum) 0,0000012 dan nilai tertinggi (maximum) 0,44. Sedangkan, standar deviasinya sebesar 0,01035 dan nilai rata-rata (mean) yaitu sebesar 0,0714. Standar devisasi lebih kecil dari skor rata-rata menunjukan bahwa political cost sebaran skornya semakin dekat dari skor rata-ratanya, yang mengindikasikan respon terhadap political cost tidak bervariasi.

Variabel kinerja lingkungan $\left(\mathrm{X}_{3}\right)$ mempunyai nilai terendah (minimum) 1,00 dan nilai tertinggi (maximum) 2,84. Sedangkan, standar deviasi sebesar 0,65075 dan nilai rata-ratanya (mean) yaitu sebesar 1,2633. Standar devisasi lebih 
kecil dari skor rata-rata menunjukan bahwa kinerja lingkungan sebaran skornya semakin dekat dari skor rata-ratanya, yang mengindikasikan respon terhadap kinerja lingkungan tidak bervariasi.

Variabel Environmental Disclosure (Y) mempunyai nilai terendah (minimum) 0,59 dan nilai tertinggi (maximum) 0,88. Sedangkan, standar deviasi sebesar 0,07514 dan nilai rata-ratanya (mean) yaitu sebesar 0,7568. Standar devisasi lebih kecil dari skor rata-rata menunjukan bahwa Environmental Disclosure sebaran skornya semakin dekat dari skor rata-ratanya, yang mengindikasikan respon terhadap Environmental Disclosure tidak bervariasi.

Pengujian asumsi klasik merupakan pengujian yang harus dilakukan sebelum melakukan analisis regresi linear berganda. Uji asumsi klasik dalam penelitian ini terdiri atas uji normalitas, uji autokorelasi, uji multikoliniearitas, dan uji heteroskedastisitas. Penelitian yang baik setidaknya harus memiliki model dengan residual yang memiliki distribusi normal. Oleh karena itu, uji normalitas dilakukan untuk menentukan hal ini, dengan memanfaatkan uji Kolmogorov Smirnov. Pengujian ini dikatakan lolos apabila nilai Asymp. Sig (2tailed) $>$ a.

Tabel 4. Hasil Uji Normalitas Data

\begin{tabular}{llr}
\hline $\mathrm{N}$ & & Unstandardized Residual \\
Normal Parameters ${ }^{a, b}$ & Mean & 56 \\
& Std. Deviation &, 0000000 \\
Most Extreme Differences & Absolute &, 07364710 \\
& Positive &, 107 \\
& Negative &, 107 \\
Test Statistic & & -.096 \\
Asymp. Sig. (2-tailed) & &, 799 \\
\hline
\end{tabular}

Sumber : Data Penelitian, 2018

Berdasarkan hasil uji normalitas dengan menggunakan One Sample Kolmogorov-Smirnov test nilai signifikansi Asymp. Sig. (2-tailed) yaitu 0,546 yang berarti nilai tersebut lebih besar dari $0,05 \quad(0,546>0,05)$ sehingga dapat disimpulkan bahwa semua data berasal dari populasi berdistribusi normal dan model regresi dapat diterima untuk dilakukan analisis tahap selanjutnya.

Uji autokorelasi dilakukan menggunakan Uji Durbin-Watson (DW-test) atau d statistik. Model regresi tidak terdapat autokorelasi apabila nilai Durbin-Watson lebih besar dari batas (du) dan kurang dari 4-du.Untuk menjelaskan ketentuan daerah terjadinya autokorelasi positif atau negatif, maupun tidak terjadi autokorelasi, dapat dilihat pada Tabel 5.

Tabel 5. Hasil Uji Autokorelasi

\begin{tabular}{lcrrrr}
\hline Model & $R$ & $R$ Square & $\begin{array}{c}\text { Adjusted } R \\
\text { Square }\end{array}$ & $\begin{array}{c}\text { Std. Error of the } \\
\text { Estimate }\end{array}$ & Durbin-Watson \\
\hline 1 & $0,898^{\text {a }}$ & 0,806 & 0,716 & 0,07574 & 1,805 \\
\hline
\end{tabular}

Sumber: Data Penelitian, 2018

Tabel 5 menunjukkan hasil uji Durbin Watson dalam penelitian ini diketahui bahwa nilai DW sebesar 1,805 yang berarti nilai DW berada diantara dU $(1,6830)$ dan 4-dU $(2,317)$; $(1,6830<1,805<2,317)$ maka dapat disimpulkan bahwa tidak terjadi autokorelasi dalam model regresi penelitian ini. 
Uji multikolinearitas dilakukan dengan melihat nilai korelasi antar variabel bebas yang dilihat dari nilai tolerance dan nilai variance inflation factor (VIF). Apabila nilai tolerance lebih dari 0,1 dan VIF kurang dari 10, maka tidak terjadi multikolinearitas.

Tabel 6. Hasil Uji Multikolinieritas

\begin{tabular}{clrrl}
\hline No & Variabel Bebas & Tolerance & VIF & Keterangan \\
\hline 1 & Ukuran Perusahaan & 0,808 & 1,237 & Bebas Multikolinieritas \\
2 & Political Cost & 0,807 & 1,239 & Bebas Multikolinieritas \\
3 & Kinerja Lingkungan & 0,998 & 1,002 & Bebas Multikolinieritas \\
\hline
\end{tabular}

Sumber: Data Penelitian, 2018

Berdasarkan tabel 6 hasil pengujian tolerance menunjukan bahwa variabel bebas (independent) antara lain ukuran perusahaan, political cost, kinerja lingkungan yang memiliki nilai lebih dari 0,1 (10\%). Hasil perhitungan VIF juga menunjukan bahwa variabel bebas (independent) meliputi Ukuran Perusahaan, political cost, kinerja lingkungan memiliki nilai VIF kurang dari 10. Oleh karena itu, dapat disimpulkan bahwa tidak terjadi multikolinieritas dalam model regresi penelitian ini.

Untuk menguji heteroskedastisitas digunakan uji Glejser yang dilakukan dengan meregresikan nilai absolut dengan variabel bebasnya. Jika tingkat signifikansi masing-masing variabel bebas $>0,05$ maka Ho diterima dan dapat disimpulkan bahwa tidak terdapat heteroskedastisitas. Sedangkan, apabila tingkat signifikan < 0,05 maka Ho ditolak (terdapat heteroskedastisitas). Berikut hasil uji heterokedastisitas dengan menggunakan uji glejser.

Tabel 7. Hasil Uji Heteroskedastisitas

\begin{tabular}{|c|c|c|c|c|c|c|}
\hline \multirow{2}{*}{\multicolumn{2}{|c|}{ Model }} & \multicolumn{2}{|c|}{$\begin{array}{l}\text { Unstandardized } \\
\text { Coefficients }\end{array}$} & \multirow{2}{*}{$\begin{array}{c}\text { Standardized } \\
\text { Coefficients }\end{array}$} & \multirow[b]{2}{*}{$\mathrm{T}$} & \multirow[b]{2}{*}{ Sig. } \\
\hline & & B & Std. Error & & & \\
\hline \multirow[t]{4}{*}{1} & (Constant) &,- 0033 & 0,064 & & $-0,511$ & 0,611 \\
\hline & Ukuran Perusahaan & 0,003 & 0,002 & 0,229 & 1,539 & 0,130 \\
\hline & political cost & 0,003 & 0,070 & 0,006 & 0,043 & 0,965 \\
\hline & kinerja lingkungan & $-0,010$ & 0,010 & $-0,138$ & $-1,033$ & 0,306 \\
\hline
\end{tabular}

a. Dependent Variable: RES2

Sumber: Data Penelitian, 2018

Tabel 7 menunjukkan hasil uji heteroskedastisitas $X_{1}, X_{2}, X_{3}$ terhadap $Y$. Berdasarkan tabel 4.6, dapat dilihat bahwa $\mathrm{X}_{1}$ memiliki nilai signifikansi 0,130 yang lebih besar dari $0,05 . X_{2}$ memiliki nilai signifikansi 0,965 yang lebih besar dari $0,05 . X_{3}$ memiliki nilai signifikansi 0,306 yang lebih besar dari 0,05 . Hasil uji heterokedastisitas dengan menggunakan uji glejser menunjukkan bahwa ketiga variabel bebas yang meliputi Ukuran Perusahaan, political cost, kinerja lingkungan memiliki nilai signifikansi di atas 0,05 sehingga dapat disimpulkan bahwa data tersebut tidak mengalami heteroskedastisitas. Setelah model lolos dalam uji asumsi klasik, maka selanjutnya adalah melakukan uji hipotesis dengan regresi linear berganda. 
Tabel 8. Persamaan Regresi Linier Berganda

\begin{tabular}{|c|c|c|c|c|c|c|c|}
\hline \multirow[b]{2}{*}{ Model } & \multicolumn{2}{|c|}{$\begin{array}{l}\text { Unstandardized } \\
\text { Coefficients }\end{array}$} & \multicolumn{2}{|l|}{$\begin{array}{l}\text { Standardized } \\
\text { Coefficients }\end{array}$} & & \multicolumn{2}{|c|}{$\begin{array}{l}\text { Collinearity } \\
\text { Statistics }\end{array}$} \\
\hline & B & $\begin{array}{l}\text { Std. } \\
\text { Error }\end{array}$ & Beta & $\mathrm{t}$ & Sig. & Tolerance & VIF \\
\hline 1 (Constant) & 0,677 & 0,100 & & 6,753 & 0,000 & & \\
\hline Ukuran & 0,004 & 0,004 & 0,157 & 6,039 & 0,003 & 0,808 & 1,237 \\
\hline Perusahaan & & & & & & & \\
\hline political cost & 0,063 & 0,110 & 0,087 & 6,572 & 0,006 & 0,807 & 1,239 \\
\hline $\begin{array}{l}\text { kinerja } \\
\text { lingkungan }\end{array}$ & 0,017 & 0,016 & 0,143 & 6,053 & 0,003 & 0,998 & 1,002 \\
\hline
\end{tabular}

a. Dependent Variable: Environmental Disclosure

Sumber: Data Penelitian, 2018

Persamaan regresi dalam model penelitian ini dapat dilihat sebagai berikut.

$$
\mathrm{Y}=0,677+0,004 \mathrm{X}_{1}+0,063 \mathrm{X}_{2}+0,017 \mathrm{X}_{3}+\mathrm{e}
$$

Nilai konstanta (a) sebesar 0,677 menunjukkan bahwa jika nilai Ukuran Perusahaan, political cost, kinerja lingkungan nol, maka nilai Environmental Disclosure sebesar 0,677. Koefisien regresi untuk variabel $\mathrm{X}_{1}$ yaitu variabel Ukuran Perusahaan sebesar 0,004 menunjukkan bahwa Ukuran Perusahaan berpengaruh positif terhadap Environmental Disclosure. Koefisien regresi untuk variabel $\mathrm{X}_{2}$ yaitu variabel political cost sebesar 0,063 menunjukkan bahwa political cost berpengaruh positif terhadap Environmental Disclosure. Koefisien regresi untuk variabel $X_{3}$ yaitu variabel kinerja lingkungan sebesar 0,017 menunjukkan bahwa kinerja lingkunganberpengaruh positif terhadap Environmental Disclosure.

Koefisien determinasi sama dengan satu berarti variabel independen berpengaruh secara sempurna terhadap variabel dependen dan jika koefisien determinasi $=0$, berarti variabel independen tidak berpengaruh terhadap variabel dependen (Ghozali, 2012).

Tabel 9. Koefisien Determinasi

\begin{tabular}{llrrrr}
\hline Model & $\mathrm{R}$ & $\mathrm{R}$ Square & $\begin{array}{c}\text { Adjusted } R \\
\text { Square }\end{array}$ & $\begin{array}{c}\text { Std. Error of the } \\
\text { Estimate }\end{array}$ & Durbin-Watson \\
\hline 1 & $0,898^{\mathrm{a}}$ & 0,806 & 0,716 & 0,07574 & 1,805 \\
\hline
\end{tabular}

Sumber: Data Penelitian, 2018

Pada tabel 9 dapat dilihat bahwa nilai adjusted $\mathrm{R}$ Square sebesar 0,716 (71,6\%). Hal ini berarti 71,6\% variasi Environmental Disclosure dapat dijelaskan oleh variabel Ukuran Perusahaan, political cost, kinerja lingkungan. Sisanya $28,4 \%$ dijelaskan oleh faktor lain yang tidak disertakan dalam variabel penelitian ini. Standard Error of the Estimate adalah suatu ukuran banyaknya kesalahan model regresi dalam memprediksikan nilai Y. Pada tabel 4.8 dapat dilihat bahwa nilai Standard Error of the Estimate 0,07574, hal ini berarti banyaknya kesalahan dalam prediksi Environmental Disclosure sebesar 0,07574. Pengaruh antar variabel bebas terhadap variabel terikat dilihat melalui hasil uji F. Hasil uji F dapat dilihat pada output ANOVA dari analisis regresi. 
Tabel 10. Hasil Uji Kelayakan Model (Uji F)

\begin{tabular}{lllllll}
\hline Model & & Sum of Squares & Df & Mean Square & F & Sig. \\
\hline 1 & Regression & 0,012 & 3 & 0,004 & 8,710 & $0,006^{\mathrm{a}}$ \\
& Residual & 0,298 & 52 & 0,006 & & \\
& Total & 0,311 & 55 & & & \\
\hline
\end{tabular}

a. Predictors: (Constant), kinerja lingkungan, Ukuran Perusahaan, political cost

b. Dependent Variable: Environmental Disclosure

Sumber: Data Penelitian, 2018

Nilai signifikan F kurang dari 0,05 yaitu 0,006 sehingga dapat disimpulkan bahwa model penelitian layak untuk digunakan sebagai model regresi dan menunjukkan secara simultan terdapat pengaruh yang signifikan antara variabel bebas yaitu ukuran perusahaan, political cost, dan kinerja lingkungan terhadap variabel terikat yaitu Environmental Disclosure.

Uji $\mathrm{t}$ digunakan untuk mengetahui seberapa pengaruh variabel bebas dalam menjelaskan variabel terikat secara individual yang dilakukan dengan level signifikansi 0,05 ( $\alpha=5 \%$ ).

Tabel 11. Pengujian Hipotesis Secara Individual (Uji t)

\begin{tabular}{|c|c|c|c|c|c|c|c|}
\hline \multirow[b]{2}{*}{ Model } & \multicolumn{2}{|c|}{$\begin{array}{l}\text { Unstandardized } \\
\text { Coefficients }\end{array}$} & \multirow{2}{*}{$\begin{array}{l}\text { Standardized } \\
\text { Coefficients }\end{array}$} & \multirow[b]{2}{*}{ t } & \multirow[b]{2}{*}{ Sig. } & \multicolumn{2}{|c|}{$\begin{array}{l}\text { Collinearity } \\
\text { Statistics }\end{array}$} \\
\hline & $\mathrm{B}$ & Std. Err & & & & Tolerance & VIF \\
\hline 1 (Constant) & 0,677 & 0,100 & & 6,753 & 0,000 & & \\
\hline $\begin{array}{l}\text { Ukuran } \\
\text { Perusahaan }\end{array}$ & 0,004 & 0,004 & 0,157 & 6,039 & 0,003 & 0,808 & 1,237 \\
\hline political cost & 0,063 & 0,110 & 0,087 & 6,572 & 0,006 & 0,807 & 1,239 \\
\hline $\begin{array}{l}\text { kinerja } \\
\text { lingkungan }\end{array}$ & 0,017 & 0,016 & 0,143 & 6,053 & 0,003 & 0,998 & 1,002 \\
\hline
\end{tabular}

a. Dependent Variable: Environmental Disclosure

Sumber: Data Penelitian, 2018

Hasil uji $\mathrm{t}$ untuk variabel pertama menunjukkan nilai signifikansi ukuran perusahaan yaitu 0,003 yang mana nilai tersebut $<0,05$ yang berarti $\mathrm{H}_{1}$ diterima (koefisien regresi signifikan). Sehingga dapat disimpulkan bahwa Ukuran perusahaan berpengaruh positif terhadap Environmental Disclosure. Ukuran perusahaan menunjuukan seberapa besar atau kecilnya perusahaan tersebut (Indrajaya, 2011). Sejalan dengan teori legitimasi yang menjelaskan bahwa perusahaan dengan total aset yang besar mendapatkan tekanan lebih besar dari lingkungan karena lebih dikenal oleh masyarakat. Begitupula dalam teori stakeholders menyatakan bahwa perusahaan yang berukuran besar dimiliki oleh cukup banyak investor, sehingga para pemangku kepentingan tersebut dapat memberikan kontrolnya terhadap perusahaan. Biasanya perusahaan besar akan mengungkapkan informasi yang lebih luas dan banyak dari perusahaan kecil (Yuliawati \& Sukirman, 2015). Penelitian yang dilakukan oleh Hadjoh \& Sukartha, (2013) ukuran perusahaan yang diukur dengan logaritma total aset mempunyai pengaruh positif pada besarnya pengungkapan lingkungan dalam laporan tahunan perusahaan.

Hasil uji $\mathrm{t}$ variabel kedua menunjukkan nilai signifikansi 0,006 yang mana nilai tersebut $<0,05$ yang berarti $\mathrm{H}_{2}$ diterima (koefisien regresi signifikan). Sehingga dapat disimpulkan bahwa Political Cost berpengaruh positif terhadap Environmental Disclosure. Sebuah perusahaan yang masih menggunakan metode 
lama atau konservatif akan mendapatkan kewajiban political cost guna mengurangi tekanan yang diberikan masyarakat (Kumalasari, 2016). Itulah mengapa manajer mengambil keputusan untuk memanipulasi laba agar terlihat rendah sebagai dampak dari tingginya biaya politis. Manajer dapat memilih untuk meningkatkan laba dengan mengurangi biaya untuk melakukan kegiatan sosial, namun untuk menghindari kewajiban dari para investor untuk terus menaikkan laba, dan sekaligus sebagai cara yang tepat untuk menarik simpati masyarakat manajer dapat menurunkan laba untuk mengalokasikan bianya dalam melakukan kegiatan sosial (Agustina, et al., 2017).

Teori political cost menjelaskan bahwa manager perusahaan yang merasa berada di bawah tekanan politis dari masyarakat memberikan motivasi untuk melaporkan tanggung jawab sosial dan lingkungannya. Sejalan dengan hal tersebut, teori legitimasi menyatakan bahwa perusahaan akan memberikan informasi mengenai kegiatan kepedulian lingkungan untuk memperlihatkan kepada masyarakat bahwa perusahaan telah bertanggungjawab atas dampak yang ditimbulkan dari kegiatan usaha yang dilakukan. Biaya politis yang diproksikan dengan market share memperlihatkan bahwa perusahaan yang memiliki market share luas akan melaporkan pengungkapan lingkungan untuk mengurangi tekanan yang diterima. Penelitian ini sejalan dengan penelitian Utami \& Andreas, 2018 yaitu biaya politik berpengaruh positif pada pelaksanaan pengungkapan sosial perusahaan.

Hasil uji t pada variabel ketiga diperoleh nilai signifikansi 0,003 yang mana nilai tersebut $<0,05$ yang berarti $\mathrm{H}_{3}$ diterima (koefisien regresi signifikan). Sehingga dapat disimpulkan Kinerja lingkungan berpengaruh positif terhadap Environmental Disclosure. Kinerja lingkungan yang baik dan diungkapkan dalam laporan pengungkapan lingkungan dapat menunjukkan kepada investor bahwa perusahaan layak untuk dipertimbangkan dalam keputusan investasi (Ameici, 2016). Perusahaan yang memiliki kinerja lingkungan yang baik mengungkapkan tanggungjawab lingkungannya kepada publik untuk meningkatkan nama baik perusahaan.

Teori legitimasi memberikan penjelasan terkait perusahaan yang mengungkapkan kewajiban lingkungannya dalam laporan tahunan karena dapat mengurangi tekanan masyarakat dan meminimalkan adanya gap. Tidak hanya itu, kinerja lingkungan yang baik memperlihatkan bahwa perusahaan telah patuh pada peraturan perundang-undangan terkait kewajiban sosial perusahaan yang diberlakukan.

\section{SIMPULAN}

Laporan mengenai pengungkapan lingkungan lingkungan kini tidak hanya menjadi laporan sukarela bagi perusahaan setiap tahunnya, melainkan menjadi hal yang wajib untuk dilakukan mengingat banyaknya kerusakan lingkungan yang telah terjadi akibat dari sikap tak acuhnya perusahaan kepada lingkungan tempatnya beroperasi. Kerusakan lingkungan sebagai dampai kegiatan perusahaan nampaknya semakin menjadi perkara serius, sehingga pemerintah melalui Kementrian Lingkungan Hidup mengeluarkan peringkat PROPER untuk menilai tingkat kepedulian perusahaan pada lingkungan. Ukuran perusahaan menjadi salah satu faktor yang berpengaruh positif pada enviromental disclosure, 
sebab semakin besar ukuran perusahaan yang dinilai dari total aset yang dimiiliki, maka semakin dikenal mereka oleh masyarakat dan semakin besar tekanan untuk melakukan kegiatan sosial dari masyarakat. Selain itu, biaya politik juga turut andil dalam mempengaruhi pengungkapan lingkungan. Manajer akan menggunakan metode akuntansi yang merendahkan laba untuk digunakan dalam kegiatan sosial dan menarik minat investor. Kinerja lingkungan juga beroengaruh terhadap pengungkapan lingkungan. Perusahaan yang menunjukkan aksi yang baik dalam tanggungjawab lingkungannya akan melaporkan hal tersebut dalam enviromental disclosure dalam laporan tahunan untuk meningkatkan legitimasinya. Mengingat pentingnya enviromental disclosure, maka sudah sepatutnya bagi manajer untuk menjadikan hal tersebut sebagai hal yang wajib diungkapkan dalam laporan tahunan, demi menjaga kesinambungan operasi perusahaan.

\section{REFERENSI}

Agustina, Sulia, \& Rice. (2017). Pengungkapan Tanggung Jawab Sosial dan Nilai Perusahaan: Dari Sudut Pandang Teori Akuntansi Positif dan Corporate Governance Dari Sudut. Jurnal Dinamika Akuntansi Dan Bisnis, 4(1), 33-44.

Akrout, M. M., \& Othman, H. Ben. (2014). A Study of the Determinants of Corporate Environmental Disclosure in MENA A Study of the Determinants of Corporate Disclosure in MENA Emerging Markets. Journal of Reviews on Global Economics, 2, 46-59. https:/ / doi.org/10.6000/1929-7092.2013.02.5

Ameici, A. (2016). Pengaruh Enviromental Performance dan Hard Enviromental Disclosure terhadap Return Saham. Jurnal Imliah Universitas Bakrie, 7(1).

Berthelot, S., \& Magnan, M. (2017). Environmental disclosure research : Review and synthesis. Journal of Accounting Literature, 22, 1-43.

Burgwal, D. van de, \& Vieira, R. J. O. (2014). Environmental Disclosure Determinants in Dutch Listed Companies. Revista Contabilidade $\mathcal{E}$ Financase, 25(64), 60-78.

Cedric, D., \& Fraas, J. W. (2011). Coming Clean: The Impact of Environmental Performance and Visibility on Corporate Climate Change Disclosure. Journal of Business Ethics, 100(2), 303-322.

Clarkson, P. M., Li, Y., Richardson, G. D., \& Vasvari, F. P. (2007). Revisiting the relation between environmental performance and environmental disclosure: An empirical analysis. Accounting Organization and Society, 3, 125. https:// doi.org/10.1016/j.aos.2007.05.003

Cong, Y., \& Freedman, M. (2011). Corporate governance and environmental performance and disclosures. Advance in Accounting, Incorporating Advances in International Accounting Journal, 27(222-232).

Darus, F., \& Taylor, D. (2009). Influences of Proprietary and Political Costs on Voluntay Disclosure Relating To Financial Instruments Before and After Mandatory Requirements. Corporate Ownership \& Control, 6(4), 391-406.

Deegan, C. (2002). The Legitimising Effect of Social and Environmental Disclosure-A Theoritical Foundation. Accounting, Auditing, and Accountability Journal, 15(3), 282-311.

Dowling, J., \& J, P. (1975). Organizational legitimacy: Social values and Organizational Behaviour. Pasific Social Review, 18(1), 122-136. 
Fajrini, I. (2012). Pengaruh Biaya Politis, Leverage, dan ROE Terhadap Pengungkapan Pertanggungjawaban Sosial Pada Perusahaan Manufaktur di Bursa Efek Indonesia. Eco-Enterprenuership Seminar \& Call Paper“ Improving Performance by Improving Environment. Skripsi. Sarjana Ekonomi Fakultas Ekonomi Universitas Negeri Semarang.

Ghozali, I. (2012). Aplikasi Analisis Multivariat dengan Program IBM SPSS 23. Semarang: Badan Penerbit Universitas Diponegoro.

Gray, R. (1995). Corporate social and environmental reporting: a review of the literature and a longitudinal study of UK disclosure. Accounting, Auditing, and Accountability Journal, 8(2).

Hadjoh, R. A., \& Sukartha, I. M. (2013). Pengaruh Ukuran Perusahaan, Kinerja Keungan dan Elsposur Media pada Pengungkapan Informasi Lingkungan. E-Jurnal Akuntansi Universitas Udayana, 4(1), 1-17.

Indrajaya, G. (2011). Pengaruh Struktur Aktiva, Ukuran Perusahaan, Tingkat Pertumbuhan, Profitabilitas dan Risiko Bisnis terhadap Struktur Modal: Studi Empiris pada Perusahaan Sektor Pertambangan yang Listing di Bursa Efek Indonesia Periode 2004-2007. Akurat Jurnal Ilmiah Akuntansi, 2(6).

Kumalasari, D. N. I. (2016). Analisis Faktor-faktor yang Mempengaruhi Enviromental Disclosure pada Perusahaan di Indonesia (Studi Empiris pada Perusahaan Non Keuangan yang Terdaftar di Bursa Efek Indonesia Periode 2012-2014). Skripsi. Sarjana Akuntansi Fakultas Ekonomi Universitas Negeri Semarang.

Milne, M. J. (2017). Positive Accounting Theory, Political Costs and Social Disclosure Analyses: A Critical Look. Critical Perspectives on Accounting, 13(19), 369-395. https://doi.org/10.1006/cpac.2001.0509

Miranti, L. (2009). Praktik Environmental Disclosure dan Kaitannya dengan Karakteristik Perusahaan. Skripsi. Sarjana Akuntansi Fakultas Ekonomi Universitas Negeri Solo.

Rasio, R. (2018). KLHK Tegas Tangani Kasus Pencemaran Lingkungan. Retrieved from http:/ / www.menlhk.go.id/berita-10515-klhk-tegas-tangani-kasuspencemaran-lingkungan.html

Sahore, N. S. (2017). Environmental Disclosures and Size of Selected Indian Firms. European Scientific Journal, 515-529.

Setyorini, C. T., \& Soedirman, U. J. (2012). Corporate Social and Environmental Disclosure: A Positive Accounting Theory View Point Departement of Accountancy Economic' s Faculty. International Journal of Business and Social Science, 3(9), 152-164.

Suhardjanto, D., Tower, G., \& Brown, A. (2008). Indonesian Stakeholders' Perceptions on Enviromental Information. Journal of the Asia Pacific Centrefor Environmental Accountability, 14(4), 2-11.

Suratno, I. B., Darsono, D., \& Siti, M. (2007). Pengaruh Environmental Performance Terhadap Environmental Disclosure dan Economic Performance (Studi Empiris pada Perusahaan Manufaktur yang terdaftar di BEJ Periode 2001 - 2004). The Indonesian Journal of Accounting Research, 10(2).

Suttipun, M., \& Stanton, P. (2012). Determinants of Environmental Disclosure in Thai Corporate Annual Reports. International Journal of Accounting and Financial Reporting, 2(1), 99-115. https://doi.org/10.5296/ijafr.v2i1.1458 
Tuwaijri, S. A. Al, Christensen, T. E., \& Hughes, K. E. (2004). The Relations Among Environmental Disclosure, Environmental Performance, and Economic Performance: A Simultaneous Equations Approach. Accounting, Organizations and Society, 29(5), 447-471.

Utami, Y. P., \& Andreas, H. H. (2018). Tanggung Jawab Sosial Perusahaan dilihat dari Sudut Pandang Teori Akuntansi Positif. Perspektif Akuntansi, 1(1), 53-70.

Welbeck, E. E., Matthew, G., Owusu, Y., Bekoe, R. A., \& Kusi, J. A. (2018). Determinants of environmental disclosures of listed firms in Ghana. International Journal of Corporate Social Responsibility, 2(11), 1-12. https:/ / doi.org/10.1186/s40991-017-0023-y

Winarsih, A. M. (2015). Pengaruh Media Online, Sensitivitas Industri dan Struktur Corporate Governance terhadap Kualitas Enviromental Disclosure. Skripsi. Sarjana Akuntansi Fakultas Ekonomi Universitas Negeri Semarang.

Yuliawati, R., \& Sukirman. (2015). Faktor-faktor yang Mempengaruhi Pengungkapan Corporate Social Responsibility. Accounting Analysis Journal, $4(4), 1-9$. 